\title{
Comparison of Village-Owned Enterprises in Indonesia and Township and Village Enterprises in China
}

\begin{abstract}
Village Owned Enterprises are business entities that are carried out by the village government together with the village community to improve the village economy and make the village independent of the economy that depends on the regional or central government. Village-Owned Enterprises are not only in Indonesia, China, already has a village-owned business entity called the Township and Village Enterprises and with the presence of China' Township and Village Enterprises is able to improve the economy of its people. This study tries to compare the concepts and characteristics of Village-Owned Enterprises with Township and Village Enterprises to get concept of economic development in Indonesia. This research uses Normative research by studying Chinese economic system research with Indonesia. The results of this study regarding the economic development of a country must indeed involve the lower level of society, economic changes that exist in the lower level community or village community, with an increase in the village economy will increase in increasing regional or central economy.
\end{abstract}

Keywords: Owned Village Enterprises, Township and Village Enterprises.

DOI: $10.7176 / J L P G / 91-21$

Publication date: November 30th 2019

\section{A. Introduction}

Village Owned Enterprises in Law Number 6 of 2014 regulated in Chapter X, with 4 articles, namely Article 87 to Article 90. In Chapter X this Village Law discusses Villages that can form Village Owned Enterprises (called Badan Usaha Milik Desa) which is managed with a family spirit and mutual cooperation. Businesses that can be run by Village Owned Enterprises are businesses in the economic sector and / or public services in accordance with statutory provisions. Establishment of Village Owned Enterprises approves Village Deliberation and is stipulated by Village Regulation. Village Owned Enterprises was designed by prioritizing the role of the Village Government and its people more proportionally. The Empowerment Program supports the role of the Village Government in the implementation of the program and through Village Owned Enterprises is expected to increase the role of the Village Government in the development of the local economy / community empowerment. Village Owned Enterprises is a business entity that is wholly or most of its capital owned by the village through direct participation obtained from the village's wealth which is equipped with the utilization of assets, services, and other businesses to generate more village community welfare funds.

The economic improvement must indeed start from the government made by the village government which is related to the village government, so President Jokowi's idea said that the development of the district is very appropriate because the State of China has done that.

Township and Village Enterprises contribution to gross domestic product continued to increase until privatization, which began in 1997. The 1984 Comunist Party of China, known as Document No. 1, famous for providing formal legal support for household-based agriculture in China agreed on something to be supported. Then, in the 1984 Document Number 4, "the central government decided to change the name of the Commune Brigade Enterprisess company into a Township and Village Enterprises company, hoping to make a difference between the Townsip and Village Enterprises company from the new Reformation era and the previous Commune Bride ECBEs Maoist company. This name change, but also in further information regarding the requirements, marketing, and ownership of the Township and Village Enterprises s company that it provides, thus being accepted as: (1) Individual farmers and farmer associations will then be allowed to establish a new Tonship and Village Enterprises company, (2) 
Township and Village Enterprises companies will be allowed to buy inputs and sell their products anywhere in China, through all permitted market channels. ${ }^{1}$

China has a village business entity known as the Township and Village Enterprises (TVE's), a Township and Village Enterprises arrangement, which in the Township and Village Enterprises does not show ownership, but rather the location where the company stands and Tonwship and Village Enterprises , and there are restrictions in the line of business that is not allowed engaged in companies engaged in iron, steel, cement, fertilizer, hydroelectric and agricultural equipment. ${ }^{2}$

The Township and Village Company is a market-oriented public company under the shade of the local government located in cities and villages in the People's Republic of China. Tonwship and Village Enterprises history dates back to the State Council of the Republic of China for the first time using the term Tonwship and Village Enterprises in March 1984. Previously called the Commune and Brigade Company originating from the Great Leap Forward that existed from 1958 to 1961 and covered rural areas. $^{3}$ At that time Township and Village Enterprises had a limited role and was limited to the production of iron, steel, cement, chemical fertilizers, hydroelectric power, and agricultural equipment. However, most of Township and Village Enterprises appeared in the Reformation period of the 1980s.

Both business entities in these two different countries have the same goal, namely for the welfare of rural communities in the country with different characteristics and characteristics between Village Owned Entreprises in Indonesia and Township and Village Enterprises, which is the core of this business entity is to prioritize the welfare of the people by building business entities, the state no longer functions as a regulator but as a businessman to make the country's economy progress and develop.

Researcher's interest in these two forms of business entity is unique between the two characteristics, unlike the company as well as pseudo-private management and accountability or with the spirit of kinship or local cultural philosophy, making the researchers make a second comparison to get an accurate picture of the village-owned enterprise in order to advance and independent like Township and Village Enterprises in China which can prove its existence as a profitable and advanced business entity.

\section{B. Research Method}

Normative legal research is a process for finding legal rules, legal principles and including legal doctrine in order to answer existing legal problems. This is consistent with the prescriptive character of legal science. Legal research is conducted to be able to produce debates, theories and new thoughts as a prescription in solving the problems faced, so that later the answers expected in legal research are appropriate, proper or improper. ${ }^{4}$ This study uses a comparative law approach (Comparative approach) used by researchers in terms of research problems over the absence of norms meaning that there are no norms that can be applied in certain legal events or completely new norms are needed to regulate the position, duties and authority of a state institution that necessary according to the dynamics of state administration, a comparative approach is always carried out by comparing the legal system of one country with the legal system of another country between the constitutions of one country and the constitution of another country to take positive things to complete the legal system of the research country. ${ }^{5}$ The comparative law approach in this study is the approximation used to compare village-owned enterprises in Indonesia with other countries such as Township and Village Enterprises in China.

\section{Results and Discussion}

The results of this study link the village-owned enterprises with Township and Village Enterprises in China with the aim of comparing the two legal systems of the two countries to get the right economic system that will be applied to the research country. Village-Owned Enterprises and Township and Village's Enterprises are both business entities that are built by rural communities to advance the village

\footnotetext{
${ }^{1}$ Cheng, Jin. (2017). An Economic Analysis of The Rise and Decline of Township and Village Enterprises. China: Palgrave Macmilan, p. 69.

2 IFPRI Discussion Paper 00854 April 2009 The Evolution of Chinese Entrepreneurial Firms Township-Village Enterprises Revisited Chenggang Xu Xiaobo Zhang Development Strategy and Governance, p. 1.

${ }^{3}$ Russle, J. et. al. (2012). Township and Village Enterprises. Scotland Untited Kingdom: Lennex Corp, p. 5.

${ }^{4}$ Marzuki, P. M. (2005). Penelitian Hukum. Jakarta: Kencana- Prenada Media Group, p. 35.

${ }^{5}$ Efendi, J. and Ibrahim, J. (2018). Metode Penelitian Hukum Normatif dan Empiris. Jakarta: Prenada Media Grup, second eddition,p.125.
} 
economy with economic sectors in accordance with the village's potential or Township and Village Enterprises in accordance with directions from local and central government.

That the village-owned enterprises and Township and Village Enterprises have unique characteristics where the Village-Owned Enterprises are business entities owned by the village government and village communities and business entities that manage to use the local cultural business philosophy and allocate their profits for social interests. Township and Village Enterprises have unique characteristics in their ownership and corporate governance arrangements. Many companies are owned jointly, meaning that ownership is shared or collective and the highest ownership rights remain in the hands of the collective, while "usage rights" are delegated to managers at Township and Village Enterprises. ${ }^{1}$

Both business entities that have unique and different management but can realize rural economic improvement in China and Indonesia. The principle of business management based on the principle of joint ownership is indeed difficult to explain clearly the right form because the mechanism of accountability for these two business entities will look different unlike in general companies running profit-oriented businesses but collective ownership makes organs in these business entities not clearly acting both actions in running a business or legal action, because the authority possessed by the business entity and its organs is made separately but the accountability mechanism in groups. ${ }^{2}$

Township and Village Enterprises is supported by local governments by providing political support for Township and Village Enterprises companies, especially in order to extend the career of entrepreneurs. Control and support for this company by providing assistance to Township and Village Enterprises and entrepreneurs gradually gaining the right to maintain their company's profits within the company, and they soon realized that control rights combined with use rights for residuals (profits) created a form of pseudo-private ownership that could provide the same benefits obtained from full private ownership. local governments can assist in providing the inputs needed by

Township and Village Enterprises companies are for daily production, so Township and Village Enterprises companies depend on local governments to get access to income, such as bank loans, labor and land. This dimension is referred to in the literature as' imperfections of the market environment. Provincial, district and city regional governments as well as member village governments provide grants and access to capital and do technical assistance and market access and prioritize the village-owned enterprises in managing village potential here, which is tasked by Provincial, district / city regional governments to encourage economic development. ${ }^{3}$ The discussion was carried out by discussing one by one about Township and Village Enterprises and the village-owned enterprises in the discussion of the results of this study.

\section{Township and Village Enterprises}

Township and Village Enterprises are market-oriented public companies under the auspices of the regional government established in cities and villages in the People's Republic of China. The State Council of the Republic of China first used the term Township and Village Enterprises in March 1984. It was published by the Commune and Brigade Company which was issued from the Great Leap Forward that existed from 1958 to 1961 and was updated in the area. At that time TVE had a limited role and only supported the production of iron, steel, cement, chemical fertilizers, hydraulic power, and agricultural equipment. However, most of Township and Village Enterprises appeared in the Reformation period of the 1980s (Huang, 2008). Although there were 12 million Township and Village Enterprises in 1985, whereas in the 1978 Reform period there were only about 1.5 million Township and Village Enterprises. As summarized by Huang: obviously, most of Township and Village Enterprises does not support Great Leap Forward. ${ }^{4}$

Township and Village Enterprises are the most important part of the Chinese economy because they need a significant expansion in the 1080s and early 1990s. Farmers' income in the midle 1980s increased stagnation, and the Towship and Village Enterprises provided excellent facilities for producing non-grain and non-agricultural production. The development of this company also competed with the local government at that time, which saw the Towship and Village Enterprises as a source of fixed income within a limited resource environment. Employment created by the Township and Village Enterprises

\footnotetext{
${ }^{1}$ Op.cit, Jin, C. (2017). An Economic Analysis of The Rise and Decline of Township and Village Enterprises. China: Palgrave Macmilan,p. 75.

${ }^{2}$ Ibid, p. 6.

${ }^{3}$ Yustisia,T. (2015). Undang-Undang Nomor 6 Tahun 2014 Tentang Desa dan peraturan terkait dilengkapi dengan SKB Tiga Menteri Terbaru. Jakarta: Visi Media, p. 88.

${ }^{4}$ Op.Cit, Russel, J. et. al. (2012). Township and Village Enterprises Scotland Untited Kingdom: Lennex Corp, p. 6.
} 
grew from 28 million in 1978 and reached a peak of 135 million in 1996. In provinces such as Jiangsu and Shandong, Township and Village Enterprises has employed around $30 \%$ of the rural workforce. ${ }^{1}$

Township and Village Enterprises refers to the location of the company, which is contrary to the ownership structure, that is not to refer to a company owned by the city and village, but rather to a company located in the city and village. In his book Huang (2008) quoted from a Chinese Ministry of Agriculture document from 1984 that supports this, it states: Township and Village Enterprises are companies sponsored by cities and villages, alliance companies (private stock companies) formed by farming communities, companies other alliances, and individual companies. Some Township and Village Enterprises are known for their unique ownership and corporate governance arrangements. Many of these companies are "jointly owned" in the sense that ownership is theoretically in the joint hands, either as a legacy of the previous sponsors, or because the city and village government established Township and Village Enterprises new after the separation of collective agriculture. The highest "ownership rights" remain in the collective hands, while the "usage rights" are delegated to managers in the collective Township and Village Enterprises. The complexity of this arrangement causes the rights of the collective Township and Village Enterprises (city and village) to become vague. The lack of a real property rights system can result in ownership rights falling in a short time, because cities and villages can take over their ownership rights. ${ }^{2}$

Township and Village Enterprises are very flexible in terms of organizational structure and ownership. While some are run by local governments, others are purer in nature. The Wong government has shown that during the 1980s most Township and Village Enterprises were collectively run as were private companies. In this sense, the use of the term collective involves the privatization of rural enterprises at a time when some people consider it to be contrary to their ideology. Township and Village Enterprises developed rapidly from 1978 to 1989, and most were disbanded between 1989 and 1996. Scholars have given a number of opinions on this success. Political institutions liked these public companies during the early years of reform, because private businesses faced severe restrictions and discrimination in terms of resources and regulations.

Township and Village Enterprises is defined by two definitions namely the first relating to ownership, and the second, relating to ownership identity. The definition of Township and Village Enterprises company is related to ownership, so Township and Village Enterprises company is defined as: 'a socially owned economic entity collectively' at the beginning of China's economic reform (State Council 1979a). Then, according to the Chinese Communist Party Central Committee and the State Council, Township and Village Enterprises company is defined as a company established by communes or brigades (government), or operated by communes or brigades' members (Central Committee of the Chinese Communist Party and State Council of the People's Republic of China 1984). Thus, the official definition of 1984 can be seen as a change in ownership: it allows individuals to run a business as a single household (trade). The 1996 Law on Township and Village Enterprises Company clearly states Township and Village Enterprises company refers to the economic organization (belonging to) rural colleagues (owned) or farmers invested in these companies' which has enlarged the definition of ownership to private property, larger in scale of business (trade) than on a company scale. "

The second definition, Township and Village Enterprises companies in terms of the identity of company ownership, that is, companies owned by the commune if initially founded by the commune, (and) are owned by the brigade if initially founded by the brigade and Commune Brigade Enterprises may not be nationalized' (State Council 1979b), and the 1984 Act reaffirms this. Then, the 1996 Law on Township Enterprise eased this limitation a little, but it still ordered that at least the main investors should be farmers or rural communities. Such owner identity requirements must also be reflected in official data sources: by 1997 law, namely China's annual report on Township and Village companies (which are data for 1996) still defines Township and Village Enterprises company as a company owned by rural communities. Significant changes occurred the following year because the new Township and Village Enterprises company registration rules were issued by the Ministry of Agriculture at the end of 1997 (Report of the Ministry of Agriculture 1997), in this new regulation the actual physical location became the criteria of Township and Village Enterprises company, as long as the company (or its headquarters) was located in rural areas, then it is defined as Township and Village Enterprises company. "

The main problem in this study of Township and Village Enterprises company is the relationship between the company and the government. In fact, two such relationships require consideration: first, that between Township and Village Enterprises company and the central government and the central planning

\footnotetext{
${ }^{1}$ Ibid, p7.

2 Jin, C. (2017). An Economic Analysis of The Rise and Decline of Township and Village Enterprises. China: Palgrave Macmilan, p. 76.
} 
system is under the control of the central government (for example, the State Owned Enterprises sector); secondly, between Township and Village Enterprises company and the local government (specifically the municipal government). In the case of Township and Village Enterprises company relations with the central government, as shown in Township and Village Enterprises company history, Township and Village Enterprises companies are not intended to be part of China's central planning system, but they are expected to be self-funded and community-based companies. The most significant aspect of the relationship between Township and Village Enterprises company and the central government lies in the role of the central authority as the source of Township and Village Enterprises company legal status. This origin can be found in the legalization of Commune Brigade Enterprises since the Mao Era, which gave status as the only form of company that was not included in the central planning authority. This does not mean that the central planning system does not exist on Township and Village Enterprises / Commune Brigade Enterprises: indeed, but the role of the central planning system is only as a giver, because prior to making purchases from State Owned Enterprises, Commune Brigade Enterprises received cash income and this was the most valuable 'gift', or prizes, which are available for Commune Brigade Enterprises from Satet Owned Enterprises. The 1978 reforms enabled another route for sending cash to CBE: through the market. Commune Brigade Enterprises can obtain significant (maybe even greater) revenue from nonState Owned Enterprises customers, but also requires industry input that can only be fulfilled by State Owned Enterprises (such as between Township and Village Enterprises and State Owoned Enterprises. ${ }^{1}$

The relationship between Township and Village Enterprises company and the regional government is geographically closer than between Township and Village Enterprises and the central government. There are two main areas in which local governments can support Township and Village Enterprises companies. First, local governments have been able to provide political support for Township and Village Enterprises companies, especially in order to extend the career of entrepreneurs. This type of assistance can be considered as support for rights control over Township and Village Enterprises company After 1978, entrepreneurs gradually gained the right to retain their corporate profits within the company, and they soon realized that control rights combined with use rights for residuals (profits) created a form of pseudo-private ownership that could provide the same benefits as ownership. full private The second area where local governments can assist in providing the inputs needed by Township and Village Enterprises companies for daily production. With a market that is tightly regulated by the Central Communist Party, Township and Village Enterprises companies depend on local governments to gain access to income, such as bank loans, labor and land. This dimension is referred to in the literature as 'imperfections in the market environment' (Li, 1996). ${ }^{2}$

\section{Village-Owned Enterprises}

Regulations on Village Owned Enterprises are Article 108 of the Local Government Act No. 22 of 1999, which was subsequently replaced by Law on Regional Government Number 32 of 2004 in article 213 and then the current and current regulations on Owned Enterprises Villages in the Village Law Number 6 Year 2014 in articles 87 to article 90

Village Owned Enterprise Capital which is all of the capital from the village which is carried out by direct or indirect participation as well as capital accumulation originating from the village community whose wealth is separated for asset management and services and other businesses to improve the village community. ${ }^{3}$ The Village Owned Enterprise was established through an agreement carried out by the village community through a village meeting through a village meeting and established by village regulation, a Village - Owned Enterprises management organization separated from a village Government Organization and a Village Owned Enterprises management with a family spirit and mutual cooperation.

The purpose of the Village Owned Enterprise is the independence of the village economy but the independence of the village is also limited by two main issues, the first is administrative / economic independence and the composition of the village budget, the freedom of the village in managing village income, village assets and village businesses, the second is political independence can be seen from the process of political independence recruitment / formation of the apparatus, accountability of the

\footnotetext{
${ }^{1}$ Jin, C. (2017). An Economic Analysis of The Rise and Decline of Township and Village Enterprises. China: Palgrave Macmilan, p. 75.

${ }^{2}$ Ibid, p. 76.

${ }^{3}$ Direktorat Pengembangan Usaha Ekonomi Desa Direktorat Jenderal Pembangunan dan Pemberdayaan Masyarakat Desa, (2016). FAQ tentang Bum Desa. Jakarta: Direktorat Pengembangan Usaha ekonomi Desa direktorat Jenderal Pembangunan dan Pemberdayaan masyarakat desa, p. 9.
} 
apparatus, the realization of political rights / community participation, independence in policy making, freedom in expressing the rights of village origins and customs. ${ }^{1}$

The purpose of Village Owned Enterprises is in line with constitutional mandate, namely the welfare of the community, especially rural communities, the country adheres to the concept of a welfare state welfare state which is a typical form of a 20th century country usually called a welfare state, or more broadly, a welfare regulator, basically an active state, namely interventionist state. Government is everywhere. The state collects large amounts of tax money, and leads a large army of civil servants. The state distributes billions in the form of welfare payments. In many countries, he runs railroads, postal services, telephones, in other countries he has banks, steel mills and other companies in his portfolio, (some of them even can generate profits). It also controls the economy (or tries to). Have a hand on the money supply. The state instructs businesses about what they can and cannot do. ${ }^{2}$

That the welfare state runs easily is not just an obstacle as illustrated in the book From poor law to welfare state and the American working class. Over the last fifteen years, the literature on social welfare has, in fact, been dominated by critics from the left, those who advocate the so-called social control thesis, namely the argument that the middle and upper classes have designed and used institutions. national welfare institutions and agents whose aim is not to help but to control those in need with the aim of preserving the existing class system, perpetuating capitalism, and serving their own interests. The concept of the welfare state is a concept that prioritizes the state or the government not merely as the guardian of security or public order, but it becomes the backbone or the priority of the responsibility for realizing social justice and welfare. ${ }^{3}$

Law Number 6 of 2014 concerning Villages regulates Village Owned Enterprises, Villages can establish the Village Owned Enterprises through village deliberations and stipulated by village regulations, however, Village Owned Enterprises management organizations are separate from village government organizations. Village Owned Enterprises is managed with the spirit of kinship and mutual cooperation, and the purpose of establishing Village Owned Enterprises is:

1.Improve the village economy

2.Optimizing village assets to be useful for village welfare

3.Increase community efforts in managing the economic potential of the village

4.Develop business cooperation plans between villages or with third parties

5.Create market opportunities and networks that support citizens' general service needs

6.Open employment

7.Improve the welfare of the community through improving public services as well as the growth and

participation of the village economy

8.Increase the income of the village community and the original income of the village.

The village economy is an effort to develop Indonesian society through villages for the maximum extent of village matching based on village economic activities and if government programs towards empowering village communities and strengthening the economy to the village finances then villageowned enterprises will improve the village economy in various sectors, especially public services. ${ }^{4}$ Village economic development is the utilization of village potential because many villages have potential for the economy, for example villages close to raw materials so as to maximize agricultural potential and encourage the involvement of rural communities to increase village income. ${ }^{5}$ Village income sources are managed through the Village Revenue and Expenditure Budget, village financial management is carried out by the village head as outlined in the village regulation on the Village Revenue and Expenditure Budget. Village financial administration by making village planning and spending and is accountable to village deliberations and determined by village regulations. ${ }^{6}$

Increasing Village Economy is the government's effort to realize the fulfillment of the economic rights of rural communities where village improvement can be seen from the economic development of the village through the production capability of the village potential and also the village status change which is said to be a backward village that is not left behind and indeed cannot be denied seen from the

\footnotetext{
${ }^{1}$ Suharto, D. G. (2006). Membangun Kemandirian Desa. Yogyakarta: Pustaka Pelajar, p. 220.

${ }^{2}$ Walter the Gruyter. (1985). Dilemmas of law in the welfare state. Berlin: Newyork, de gruyter, p. 13.

${ }^{3}$ Walter I. Trattner. (1999). From Poor Law to Welfare State. America: The Free Press, p. xxiv.

${ }^{4}$ Sudarsa, A. G. (2002). Membangun Indonesia Sejahtera. Jakarta: Graha Pena, p. 240-241.

${ }^{5}$ Yustika,A.E. (2017). Sejahtera Dari Desa Refleksi Pemberdayaan Berbasis Potensi Pertanian. Malang: Averroes Press,

${ }^{6}$ Soemantri, B.T. (2011). Pedoman Penyelenggaraan Pemerintahan Desa. Bandung : Fokus Media, p. 136.
} p. 168. 
facilities and infrastructure that are increasing or fulfilled, but in empowering the village community through the Village Owned Enterprises is directed at developing the potential of each village so that the potential can be managed well by the village community.

Villages can now establish Village - Owned Enterprises in their implementation is not as easy as expected from the purpose of the Village Law because up to now almost 4 (four) years of the Village Law is enacted there are still many villages that have not established Village Owned Enterprises due to the variety factors such as Human Resources, Natural Resources and the lack of knowledge from village officials on this matter. This can be proven by the data of Village-Owned Enterprises that already exist in Indonesia. Village records according to the Rural Ministry of Villages currently number 74,957 villages (seventy four thousand and nine hundred fifty-seven), and Villages that alreday have Village Owned Enterprises are 32,249 (Thirty-two Thousand two hundred and forty-nine Village Owned Enterprises). This Figure shows that not all village in Indonesia have formed or have Village Owned Enterprises in accordance with the mandat of the village law. The figure also shows that the development of Owned Village Enterprises has Greatly increased in only a perioed of almost four years and almost half of the villages have Village Owned Enterprises. ${ }^{1}$

From the data mentioned above, the number of villages that already have Village Owned Enterprises are also many villages that have said that they have developed and developed with Village Owned Enterprises owned such as Village Owned Enterprises in the villages of success of Village Owned Enterprises, namely: Village Owned Enterprises of Karangkandri Sejahtera, Karangkandri Village, Kesugihan Cilacap District with business units supplying various needs for Steam Power Company and Village Owned Enterprises "Karangkandri Sejahtera" to supply bolder stones needed by for the Steam Power Company . Village Owned Enterprises, Tirta Mandiri, Manage Ponggok attractions, Ponggok Village, Polan District, Klaten. A natural swimming pool that has a myriad of unique attractions for its visitors. Village Owned Enterprises Srisadani, Kedungprimen, Bojonegoro Village Owned Enterprises Srisadani develops the pumping business of tero rental in agriculture and earns Rp. 1.3 billion per year. Village Owned Enterprises Tirtonirmolo Village Owned Enterprises, owned by Kasihan Village, Bantul, is developing a savings and loan business unit. Village Owned Enterprises of Sejahtera Bleberan, Bleberan Village Gunung Kidul Yogyakarta manages Sri Getuk waterfall. That is the five best Village Owned Enterprises on the island of Java. The five developed Village Owned Enterprises can be an example for other Village Owned Enterprises throughout Indonesia to be able to improve management capabilities so that they can become developed Village Owned Enterprises and can improve the economy of the villagers. ${ }^{2}$

Village Owned Enterprises in Klaten is a very developed Village Owned Enterprises because in addition to being able to demonstrate success it has also become a pilot Village Owned Enterprises for other villages in Indonesia. Following is a description of the Articles of Association for the establishment of BUM Desa in Klaten with this village-style business entity called Desa Tirta Mandiri, with the abbreviation BUMDES "Tirta Mandiri", and henceforth called "BUM Desa" BUM Desa is a villageowned legal entity, was formed based on the authority based on the origin rights and local authority on a village scale and determined by the Village Regulation.

The mention of the name Village Owned Enterprises as meant has the meaning: Tirta word, is a symbol of water that shows the uniqueness and solemnity of the natural resources of Ponggok Village; and Mandiri word, is a symbol of the ability of Ponggok Village to stand on its own to manage economic potential, natural resources, and basic services for villagers; The position of Village Owned Enterprises of Tirta Mandiri is in Ponggok Village - Polanharjo District, Klaten Regency, Central Java Province. Village Owned Enterprises as intended can be based in the Village area, both inside the Village Government office and outside the Village Government office. Other villages that have sought to empower and motivate village communities to establish village-owned enterprises as carried out by the Blitar district government by establishing six Village Owned Enterprises in accordance with the potential of the village.

The second discussion makes a complete understanding about that the business entity owned by the state, especially the village government, is a tool for the state in the context of realizing economic independence, with the greatest hope being to improve the village economy for a broader sector. The uniqueness of ownership and management is an illustration for a village-owned enterprises is a business

1 Mahesa, O. A. (2018). Jumlah BUMDes di Indonesia Sudah 32 Ribu Lebih. [Online] Available http://finansial.klikpositif.com/baca/33059/jumlah-bumdes-di-indonesia-sudah-32-ribu-lebih,(june 6, 2018).

2 Berdesa.com. (2017). Ini Dia Lima BUMDES Terbaik di Pulau Jawa. [Online] Available http://www.berdesa.com/ini-dia-lima-bumdes-terbaik-di-pulau-jawa/, (February 28, 2018). 
entity that puts forward the philosophy of local culture so that it has its own uniqueness from other business entities.

\section{Conclusions}

From the discussion and results of the research as described above, it can be concluded that the village-owned business entity is an effort by the government of the Local to realize economic independence by establishing a village-owned neterprises which is an area directly in contact with the people in a country. The management and establishment of village-owned enterprises in Indonesia and Township and Village Enterprises have the same and unique characteristics except that the form of legal entity in Township and Village Enterprises in China is explained in the form of companies in villages or municipalities but villageowned enterprises do not clearly state the status of legal entities of business entities which clearly has very broad legal implications in terms of status and management and responsibility. Township and Village Enterprises in China explicitly refers to it as a company and the Law expressly regulates the management procedures and responsibilities and support of local governments so that Township and Village Enterprises runs well and benefits society.

To the Central and Regional Governments both Provinces / Regencies to encourage the policy of establishing Village Owned Enterprises for one village, Village Owned Enterprises by implementing the program that has been declared by and becoming a supervisor for Village Owned Enterprises management in order to achieve the right goal, namely community welfare because Village Owned Enterprises is a commercial institution and social institutions for village communities.

\section{Reference}

Berdesa.com. (2017). Ini Dia Lima BUMDES Terbaik di Pulau Jawa. [Online] Available http://www.berdesa.com/ini-dia-lima-bumdes-terbaik-di-pulau-jawa/, (February 28, 2018).

Direktorat Pengembangan Usaha Ekonomi Desa Direktorat Jenderal Pembangunan dan Pemberdayaan Masyarakat Desa, (2016). FAQ tentang Bum Desa. Jakarta: Direktorat Pengembangan Usaha ekonomi Desa direktorat Jenderal Pembangunan dan Pemberdayaan masyarakat desa.

Efendi, J. and Ibrahim, J. (2018). Metode Penelitian Hukum Normatif dan Empiris. Jakarta: Prenada Media Grup, second eddition.

IFPRI Discussion Paper 00854 April 2009 The Evolution of Chinese Entrepreneurial Firms Township-Village Enterprises Revisited Chenggang Xu Xiaobo Zhang Development Strategy and Governance.

Jin, C. (2017). An Economic Analysis of The Rise and Decline of Township and Village Enterprises. China: Palgrave Macmilan.

Mahesa, O. A. (2018). Jumlah BUMDes di Indonesia Sudah 32 Ribu Lebih. [Online] Available http://finansial.klikpositif.com/baca/33059/jumlah-bumdes-di-indonesia-sudah-32-ribu-lebih,(june 6 , 2018).

Marzuki, P. M. (2005). Penelitian Hukum. Jakarta: Kencana- Prenada Media Group.

Russle, J. et. al. (2012). Township and Village Enterprises. Scotland Untited Kingdom: Lennex Corp.

Sudarsa, A. G. (2002). Membangun Indonesia Sejahtera. Jakarta: Graha Pena.

Suharto, D. G. (2006). Membangun Kemandirian Desa. Yogyakarta: Pustaka Pelajar.

Soemantri, B.T. (2011). Pedoman Penyelenggaraan Pemerintahan Desa. Bandung : Fokus Media.

Walter the Gruyter. (1985). Dilemmas of law in the welfare state. Berlin: Newyork, de gruyter.

Walter I. Trattner. (1999). From Poor Law to Welfare State. America: The Free Press.

Yustika, A.E. (2017). Sejahtera Dari Desa Refleksi Pemberdayaan Berbasis Potensi Pertanian. Malang: Averroes Press.

Yustisia,T. (2015). Undang-Undang Nomor 6 Tahun 2014 Tentang Desa dan peraturan terkait dilengkapi dengan SKB Tiga Menteri Terbaru. Jakarta: Visi Media. 